\title{
Role of Meditative Foundation Entrepreneurial Leadership and New Venture Success
}

\author{
Malavika Sundararajan \\ North Carolina Central University, Durham, NC \\ Binod Sundararajan \\ Dalhousie University, Halifax, NS, Canada \\ Sybil Henderson \\ North Carolina Central University, Durham, NC
}

\begin{abstract}
The inability of CEOs and founders to be effective leaders has been one of the chief reasons identified for nearly $80 \%$ of new venture firms' failures within the first five years of being established. Entrepreneurial leadership has thus begun to garner increased attention as a result of the recognition that entrepreneurs cannot successfully develop new ventures without displaying effective leadership behaviors. While current leadership theories applied to entrepreneurial settings prescribe changing from transformational to transactional as per the environmental demands, a more foundational theory of entrepreneurial leadership that can be consistently implemented through all the phases of new venture creation and management is currently lacking. In order to provide a more consistent leadership style, based on the theory of meditative foundation, our paper proposes a spiritual entrepreneurial leadership model that can support new venture success by increasing founders' and CEOs' ability to be effective leaders in varying scenarios.
\end{abstract}

Key words: Meditative foundation; Entrepreneurial leadership; New venture success

\section{INTRODUCTION}

The high failure rate among new ventures has driven several research efforts aimed at understanding the dynamics of start-ups leading to their success or failure (LeBrasseur \& Zinger, 2005). To address the failure rates, research studies range from macro-level factors like strategic networks (Stuart \& Sorenson, 2007; Davidson \& Hong, 2003) and industry, size and environmental factors (Song, Podoynitsyna, Van Der Bij \& Halman, 2008; Smith \& Gannon, 1987) to micro-level factors that include the entrepreneur's traits and background (Diochon, Menzies \& Gasse, 2005); prior knowledge (Shane, 2008); creativity (Hill, 1995); cognitive factors like perception, intention, alertness (Mitchell et al., 2007; Karp, 2006; Dallenbacca, 2002; Bird, 1992) and more recently, emotions, feelings, moods, affect and passion (Foo, 2011; Cardon, Wincent, Singh \& Drnovsek, 2009; Foo, Uy \& Baron, 2009; Baron, 2008; Karp, 2006; Cardon et al., 2005). While each of the above studies observed significant impacts of the respective factors on the success and failure of a new venture, research has also identified the four most significant factors that contribute to start-up failures to be: (1) management incompetence/inefficiency (Thornhill \& Amit, 2003; Peacock 1985; McMahon et al., 1993), (2) poor financial control, (3) improper inventory control, and (4) incorrect pricing (Zimmerer \& Scarborough, 2002).

Studies that examined management competency found that higher levels of management capability, particularly in the marketing area, are indeed associated with early stage survival (LeBrasseur \& Zinger, 2005). More specifically, efforts to bolster the operation in the areas of pricing, customer service, and new service/product offerings (components of the marketing factor) appear to enhance the prospects for survival in the early stages. LeBrasseur and Zinger (2005) state that the research findings imply that there is a premium associated with the entrepreneur being able to "get over the brick wall" of intuitive decision-making and resistance to more professional management practices (Montoya, Omura \& Calantone, 1993). Thus it is

Correspondence concerning this article should be addressed to Malavika Sundararajan, School of Business, North Carolina Central University, Durham, NC, USA. email: msundara@nccu.edu 
suggested that entrepreneurial ability itself is a "unique scarce resource" that can have a constraining impact (Oi, 1983) on the outcome of a new venture. LeBrasseur and Zinger (2005) further suggest that it is only when entrepreneurs become aware of their managerial deficiencies that they can they seek practical solutions. Other small business researchers (Dyer \& Ross, 2004) recommend that in order to overcome managerial inefficiencies, in addition to having dialogues with mentors and coaches, and formalizing their business planning processes with computer programs, one should particularly encourage more awareness, selfreflection and self-examination. More specifically, an entrepreneurial leader is required to show continuous initiative and action, to effect meaningful change in a timely manner with the capacity to adapt and enhance performance to ensure long-term survival of a new venture (Prieto, 2010).

The few empirical studies in entrepreneurial leadership, however, suggest merely changing from transformational to transactional styles of leadership as per the environmental needs of the new venture (Yildrim \& Saygin, 2011; Ensley, Pearce \& Hmeileski, 2006). A more recent stream of entrepreneurial leadership research (Kauanui et al., 2008; Chu, 2007; Jackson \& Konz, 2006; Kauanui, Thomas \& Waters, 2005) has nevertheless brought to the forefront the importance of mindfulness and spiritual leadership as a means to providing a consistent framework of entrepreneurial leadership that can be implemented at all stages of a new venture's creation and management. Our paper focuses on this key aspect of creating a level of awareness, as a means to more effective leadership among entrepreneurs. This can lead to new venture success by reducing owners' inefficiencies and increasing their capabilities, when other factors like poor financial control, improper inventory control and incorrect pricing can be controlled by more professional management practices.

While several theories on spiritual leadership have been founded on Western or Eastern philosophies and religions or meditative techniques like spiritual capitalism (Chu, 2007); Rinzai Zen meditation (Bodhi Dharma from the 5th Century) or transcendental meditation (Maharishi Mahesh Yogi, 1967, 1994), our paper is based on the principles of meditative foundation described by Osho (1980) for two reasons. The first is that compared to most other meditative techniques, the Osho school of thought refers to a non-thinking silence that directly drives one to a state of knowing rather than thinking, chanting or breathing. Secondly, since creativity forms the crux of entrepreneurial thinking (Hills, 1995) we adopt meditative foundation as the basis of our model due to its specific applicability to creative people (Osho, 1980), as described further in the next section.

As we proceed, we provide a review of entrepreneurial leadership, spiritual leadership and based on earlier case study research findings and an interview case study of a local entrepreneur, propose a spiritual model of entrepreneurial leadership and new venture success. We believe that this model will provide the foundational needs of a consistently implementable leadership style during all phases of new venture creation and development.

\section{REVIEW OF LITERATURE}

\section{Current Entrepreneurial Leadership Models}

Entrepreneurial leadership is defined as leadership that creates a vision based on which the leader will assemble and mobilize a "supporting cast" of participants who become committed by the vision to discover and exploit the idea to create strategic value (Gupta, McMillan \& Surie, 2004). From the onset of a new venture, founders are indeed required to exhibit leadership in order for their businesses to take form (Ensley et al., 2006). Leadership has thus begun to garner increased attention in entrepreneurship research as a result of the recognition of the fact that entrepreneurs cannot successfully develop new ventures without displaying effective leadership behavior (Bryant, 2004; Cogliser \& Brigham, 2004).

Among the leadership models, transformational style is applicable when the entrepreneur engages in communicating long-term vision, inspiration, deeper meaning (Conger, 1989), entrepreneurial endeavors (Burns, 1978), as well as initiations critical to the growth of a new firm (Baglia \& Hunt, 1988). The emphasis on transactional style, on the other hand, is applied when the entrepreneur is required to address rational needs in the early life of a start-up, such as coordination by setting performance expectations and clarification of reward contingencies in order to leverage performance of individual behavior to achieve new venture objectives (Ensley et al., 2006). Further, new venture team members who have less experience and task maturity with startups need more directive leadership styles from their leader (Papalexandris \& Galanaki, 2009). There is also, however, a third stream of research that emphasizes the importance of pro-activeness, 
innovativeness and risk-taking dimensions of an entrepreneur's leadership style (Venkatraman \& Van de Ven, 1998; Morris, Schindehutte \& Laforge, 2004). These dimensions are shown to enable the entrepreneur to search for, and create more meaningful solutions to individual and operational problems and needs (Darling, Keeffe and Ross, 2007). These dimensions also ensure a willingness to commit resources to opportunities and helping make events happen through appropriate means, thereby enabling and motivating his or her team members to be actively and enthusiastically involved in the successful achievement of the firm's vision (Darling et al., 2007).

\section{The Gap in Current Entrepreneurship Leadership Theories}

The practice of entrepreneurial leadership focuses on addressing the need to break new ground, go beyond the known, and help to create the future (Darling, Keeffe \& Ross, 2007). However, what makes an entrepreneurial leader truly successful is his/her ability to deal with opportunities in a dynamic and constantly changing environment and therefore entrepreneurial leadership theories cannot afford to only focus on an entrepreneur's intelligence, education, lifestyle or background (Darling, Keeffe \& Ross, 2007). Empirical studies have shown a positive relationship between transformational and entrepreneurial leadership (Gupta, McMillan \& Surie, 2004), but their effects have also been observed to be complex and context-based (Ensley et al., 2006). These studies, however, do not take the importance of self-awareness into consideration and yet require the entrepreneur to be aware of when to be a transformational or transactional leader during the venture creation process, thus resulting in a gap for a more foundational entrepreneurial leadership model that can be applied across the life cycle of a new venture. This gap, nevertheless, has resulted in a more recent stream of research which explores the spiritual side of entrepreneurial leadership (Kauanui et al., 2008; Chu, 2007; Jackson \& Konz, 2006; Kauanui, Thomas \& Waters, 2005).

In the next section, we describe this new stream of spiritual leadership and introduce how the principles of meditative foundation add greater depth to this line of study.

\section{Spiritual Leadership and Entrepreneurship}

Spirituality has been defined as transformational, moral, and ethical, encompassing integrity, honesty, goodness, knowing, wholeness, congruency, interconnectedness and teamwork (Dent, Higgins \& Wharf, 2005). Extant literature indicates that spiritual leadership theory (SLT) incorporates motivation-based theories of leadership as well as religious, ethics and values-based approaches to leadership, which includes values, attitudes and behaviors, to intrinsically motivate self and others, so that they have a sense of spiritual survival through calling (Fry, 2003). Motivation in the form of intent to start a business has also been found to be a critical driving force for opportunity evaluation and development among entrepreneurs (Ciavarella et al., 2004; Krueger, Reilley \& Carsrud, 2000; Ford, 1996; Bird, 1992).

Founded on both Western and Eastern philosophies, we observe that these motivation-based theories not only include Transactional and Transformational, but also extend to Path-Goal, Charismatic, and Intrinsic Motivation. Related to SLT, Fry (2003) proposed that spiritual leadership is necessary for the transformation to occur with continued success of a learning organization, one in which expanded patterns of thinking are nurtured and people are empowered to achieve a clearly articulated organizational vision. Moreover, it must primarily motivate workers intrinsically through vision, hope and altruistic love, task involvement and goal identification. Moxley (2000) identified a call for more holistic leadership, integrating the four fundamental areas of human existence: the body (physical), the mind (logical/rational thought), the heart (emotions, feelings) and the spirit.

Spiritual leadership studies have shown that while many leaders view spirituality to be tied to religion or epiphanies they experience in life, the most predominant view is its relation to individual development leading to greater productivity and profitability (Dent, Higgins \& Wharf, 2005). Spirituality and its relationship to workplace leadership is based on the premise that, as development occurs, there is a transcending of worldviews and a shift to higher levels of internal locus of control (Sanders, Hopkins \& Geroy, 2003). Also, that human growth is achieved through the interplay of individual, community and environment and that at higher stages of development, leaders deepen their intuition and inner knowing through a shared consciousness with a higher power or transcendent (Dent et al., 2005).

The importance of the spiritual leadership model to entrepreneurs lies in the observation that leaders who bring their spirituality to work transform their organizations from merely mission-driven activities into places where individual and collective spirituality are encouraged, and spiritual development is integrated into the 
day-to-day work life (Konz \& Ryan, 1999). Interviews with CEOs and other high-ranking executives indicate that many decisions at the highest levels of all kinds of organizations are made on the basis of prayer, and that leaders of significant stature and influence care deeply about the spiritual side of their leadership roles (Harvey, 2001).

Specific to the case of entrepreneurs, spirituality is proposed as a means of increasing the connection with oneself, others and/or an ultimate reality and a need to direct and motivate self and/or others to develop an organizational culture founded on a sense of shared community (Fernando, 2008). Fernando found that the impact of this spiritual connection on the entrepreneur's approaches to leadership and consequently on the followers and organizational culture was significant. Another important study by Chu (2007) found that by juxtaposing personal spirituality and marketplace dynamics, entrepreneurs could create spiritual capital by identifying and valuing spiritual assets, mitigating inhibitors to flow and therefore harnessing an inner guidance to appropriately pursue material abundance critical for the successful financial management of the new venture.

However, for personal transformations to occur, it is suggested that leaders need to develop or enhance their spirituality through activities such as meditation, reflection, therapy (Tosey \& Robinson, 2002) and reflective thinking (Duignan \& Bhindi, 1997; Khanna \& Srinivas, 2000; Moberg \& Calkins, 2001). Studies emphasize that for leaders to lead with authenticity and integrity they must reflect on their lives to discover and understand their purposes (Korac-Kakabadse \& Korac-Kakabadse, 1997). The inner guidance from contemplation, prayer and meditation have also been hypothesized to directly impact a leader's values, attitudes, vision and therefore behaviour, which in turn results in indirectly increasing organizational profits (Kriger \& Seng, 2005). Further, meditation can increase job satisfaction and productivity and can help with "positivity" training, boost one's mood and decrease anxiety, resulting in effective decision-making, judgment, and planning (Chen, Yang $\& \mathrm{Li}, 2011)$, all of which are critical to the intuitive decision-making needs of an entrepreneur.

\section{A SPIRITUAL ENTREPRENEURIAL LEADERSHIP MODEL}

Our review of entrepreneurial leadership needs directs us to the importance of self-reflection and meditation owing to the enormity of information processing required in risky, uncertain and dynamic organizational settings that require instantaneous decision-making and creativity to continuously recognize, evaluate and develop opportunities. The spiritual leadership models also highlight the importance of meditation and reflection but a consensus is yet to be reached with respect to the manner in which this state of awareness can be attained. Of the meditation and relaxation techniques currently available, Maharishi's Transcendental Meditation (TM) program has been most widely studied (Wallace, 1993) and it involves the effortless but systematic refinement of the thought processes. Baer Smith and Allen (2004) found that the by-products of the experience of transcendental consciousness during TM practice were serving, describing, acting-withawareness, and accepting-without-judgment. While this is useful for entrepreneurs in terms of being open to change and managing their employees' rational needs, a deeper level of knowing through mindfulness that allows a state of continuous opportunity recognition and intuitive decision-making has been empirically shown to be non-existent (specifically, no impact on prefrontal alpha left-lateralized asymmetry which controls mindfulness) through the practice of TM (Travis \& Arenander, 2004). TM has also been described to be a mere process of chanting that doesn't necessarily promote a transcended state which is critical to a deeper level of knowing (Osho, 1980).

Another meditation technique is the one proposed by the Zen School of thought. While the Rinzai and Soto Zen techniques do indeed establish a connection with deeper processes, they still suggest posing a question that cannot be answered by thought or knowledge which takes a great amount of realization to become enlightened (Bodhi Dharma from the 5th Century).

The Osho school of thought (1980), on the other hand, introduces the need for a meditative foundation which is described to be a process of non-thinking and silence. This silence allows the individual to reach a more conscious state of being. However, while it is in direct conflict with ambition, a characteristic often associated with businessmen, creative persons (as entrepreneurs are often characterized to be), can more easily get into meditation and go deeper into the process of self-reflection (Osho, 1980). This makes the meditative foundation model most relevant to entrepreneurs, who are constantly required to be creative in recognizing and developing business opportunities.

The key principles of meditative foundation include: 
- Non-thinking

- Silence

- Becoming a witness to all that one does

- Not focusing on the object but on what is happening

- And finally, not making it about individualism but becoming an individual with arduous discipline through perseverance, work and watchfulness.

Meditative foundation focuses on real knowing which comes through meditation, awareness, consciousness, mindfulness, watchfulness and witnessing. Here meditation is not escaping from life but rather, escaping into life that encourages growth of one's total living. The non-thinking and silence principles, speak to the idea that the mind, as it exists, is not meditative. This is because we are invariably biased by our linguistic and intellectual thinking and interpretations of how life should be. Our biases lead us to constantly evaluate everything with reference to objects and people when we use our mind, hence also the little use of other meditation techniques offered by TM and Zen, which focus more on creating self-awareness through chanting or reflection by answering questions.

The meditative foundation process will be particularly effective for entrepreneurs, since it leads the individual to become aware of gaps in a situation, which is realized through non-verbalizing and silence of the mind. The more aware one becomes through meditative foundations of reflection the slower the mind becomes. When one becomes watchful and aware of the mind, the gaps between thoughts widen and the individual begins to see them. These gaps are described to be just like a gestalt picture. Through the practice of meditative foundation, an individual then becomes conscious of the gap in silence, and therefore becomes one with it, while remaining the watchful knower or observer. This allows one to step back from the situation and view it objectively enough to allow their creative talents to surface. This in turn clears the individual's thinking as well as leading to admitting failures but having the awareness of a reference point to not commit the same failures again (Osho, 1980).

We thus propose the spiritual entrepreneurial leadership model (see Figure 1) founded on Osho's (1980) meditative principles, which will allow entrepreneurs to sustain their leadership in an effective manner, and provide them with a critical source of inner-strength for leader-member interactions. This can lead to knowledge through clarity of thought and action that will result in greater self-actualization among both leaders and team members in small businesses due to alignment of individuals' and firm's goals.
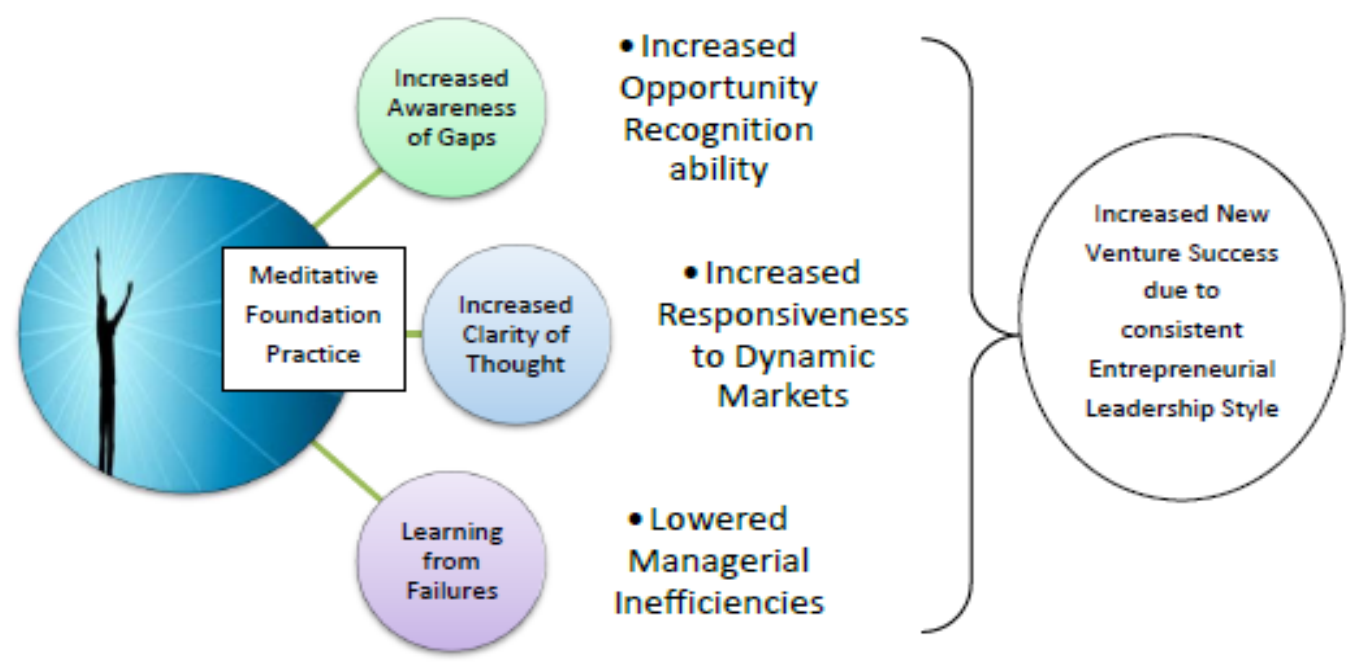

Figure 1: Role of Meditative Foundation in Entrepreneurial Leadership and New Venture Success

\section{Interview Case Study of Entrepreneurial Leader}

To understand the general patterns of leadership style that is effective among entrepreneurs, we conducted a detailed interview with a local entrepreneur, who has been the CEO of a bio-tech company, which had been 
successfully managed for 15 years by him, and has recently been acquired by a large firm for billions of dollars. The entrepreneur leader was asked four main questions:

1) What were your main responsibilities as the CEO?

2) Describe your leadership management style.

3) What does being a leader mean to you?

4) Describe specific traits that contributed to your success as a leader.

Responses were as follows:

Answer 1: Responsibilities included: responsiveness to shareholders, and communication; strategic planning and overseeing tactical day-to-day activities but primarily delegating tactical needs to senior management.

Answer 2: To delegate to the senior management team - who had the expertise and knowledge and ensured they were given clearly defined short/intermediate/long term goals, each VP had a strategy and was goaloriented. Shared vision, goals and understanding with all employees. Routinely communicated to all members, a clear mission and set of goals. Established documentation of processes, contribution needed by each employee to the goals and shared across the departments. Encouraged team-based work which matched individual goals. Ensured that, up and down and laterally all was interactive, long-term goal was clear, annual contribution goals aligned with senior management and board's goals.

Answer 3: Focus on education, experience and reputation and make sure you hold yourself to high standards. Allow others to succeed and grow, all with an awareness of inter-dependence.

Answer 4: Strong capability to communicate vision. Being able to recognize superior knowledge - spotting talent, size up people and capability, competency, what do they believe in and why, and instil courage of conviction. Focused on solving problems and removing conflicts for employees while petty stuff was not given much attention. Helped translate needs to objectives and goals, helped them to feel good about accomplishing. Need to figure out really what is important that could conceivably matter also what doesn't matter and helped clarify what mattered. Could connect more with the needs due to less cluttering of knowledge to come up with solutions. Open to change, intrigued by new ideas. Rigid about process and goals and objectives. Created values for shareholders, Stated to have high self-esteem, be self-driven, self-reliant, among which identified being trustworthy and consistent, as the most critical component that contributed to leadership success. Additionally, stated that constant self-awareness of limitations and capabilities helped him succeed.

Based on the model and the interview case study, we observe that among critical managerial needs and a simultaneous need to intuitively understand, be responsive and communicate the needs of the organization and align its goals with those of his employees, the most critical component identified by the entrepreneur was being consistent in his leadership style. Further, self-awareness of his capabilities and traits seemed to contribute to his success. While this is only a single sample, it provides a potential roadmap of patterns of entrepreneurial leadership styles that can be successful. We thus put forward four propositions.

The crux of meditative foundation is becoming aware of gaps, which also forms the basis of the entrepreneurial opportunity recognition process (Venkataraman, 1997).

Proposition 1a: Entrepreneurs who engage in developing a meditative foundation will become more aware of gaps, and will therefore exhibit an increased ability to recognize opportunities.

Chu (2007) shows that a greater clarity of thought through spiritual meditation results in an increased ability among entrepreneurs to be highly responsive to appropriate market resources in dynamic environments.

Proposition 1b: Entrepreneurs who engage in developing a meditative foundation will experience increased clarity of thought and therefore exhibit an increased ability to be responsive to dynamic markets.

Most importantly, becoming aware of and therefore learning from one's mistakes ensures increased managerial capabilities among entrepreneurs, which has been found to be critical to new venture survival and success (LeBrasseur and Zinger, 2005; Dyer and Ross, 2004).

Proposition 1c: Entrepreneurs who engage in developing a meditative foundation will experience an increased openness to admitting their failures and will learn not to repeat the same mistakes and therefore exhibit a decreased level of managerial inefficiency.

Together, as described by entrepreneurship researchers (Mitchell et al., 2007; Karp, 2006; Dallenbacca, 2002; 
Bird, 1992) increased cognitive abilities and decreased managerial inefficiencies (Dyer and Ross, 2004) will indeed result in increased new venture success. We additionally propose that this success is directly related to the availability of a consistent entrepreneurial leadership style, thus our final proposition states that: Proposition 2: Entrepreneurs with increased ability to recognize opportunities, increased responsiveness and
decreased managerial inefficiencies will exhibit a more consistent entrepreneurial leadership style leading to
a greater probability of new venture success.

\section{CONCLUSION}

Entrepreneurial leadership has received significant attention due to the unique position of influence that founder CEOs occupy serving as the locus of control and decision-making (Begley \& Boyd, 1987) in a new venture firm. The current theories in entrepreneurial leadership prescribe switching between transformational, directive or transactional styles of leadership based on the needs of the environment (Ensley et al., 2006). But without emphasizing the importance of awareness and reflective thinking, the researchers automatically assume that entrepreneurs will be self-aware and know when to switch their leadership styles based on need. This excessive focus by entrepreneurial leadership theories on intellectual pursuits alone has been unable to account for the high rate of start-up failures. By exploring a spiritual leadership perspective anchored in meditative foundation, and applying it to the context of new venture firm creation, development and management, we describe the spiritual perspective that provides a consistent foundational leadership style to entrepreneurs.

We also explain, with a description of meditative foundation principles, how the spiritual entrepreneurial leadership style can enhance creativity and clarity of thought among entrepreneurs and provide them a greater probability of success. While our research builds on existing streams of entrepreneurial studies which have introduced the concept of spiritual leadership, by emphasizing the need for following a non-thinking and silent meditative form that directly promotes entrepreneurial thinking we provide a potential model of consistently implementable entrepreneurial leadership style across the life cycle of a new venture.

We intend to test the model empirically through a pre/post simulated test that will include a series of nonthinking and silent moments during the simulation to measure increased entrepreneurial thinking patterns. The model can first be tested among students in Entrepreneurship courses and then compare them with existing small business leaders. Our initial model is directed at developing a consistent entrepreneurial leadership style; however, subsequently the model can also be tested across the board within small businesses, at different units of analysis, namely, the entrepreneurial team and the organization as a whole. The main contribution of this paper is the direct acknowledgement of the gap in empirically testable models of entrepreneurial leadership leading to new venture success by moderating the impact of previously identified factors like opportunity recognition abilities and managerial inefficiencies, through the introduction of nonthinking and silent meditative principles. This model is critical to both the academic and practitioner groups. In academia, courses can be designed to include reflective thinking sessions that will enable greater entrepreneurial leadership skill development among students. Among practitioners, this is not only a teachable model, but ensures greater and consistent probability of their firm's success.

Malavika Sundararajan is an Assistant Professor of Entrepreneurship and Management in the School of Business at North Carolina Central University, Durham, NC. Her research focuses primarily on the cognitiveemotional models of entrepreneurs, opportunity recognition and entrepreneurial leaders and extends to the areas of immigrant and social entrepreneurship.

Binod Sundararajan is an Assistant Professor of Business Communication in the Rowe School of Business at Dalhousie University, Halifax, Nova Scotia. His research interests lie in organizational, professional and business communication, computer-mediated communication (CMC), computer-supported collaborative learning (CSCL), computer-supported cooperative work (CSCW) and social network analysis as well as use of $\mathrm{CMC}$ in such diverse areas as immigrant entrepreneurship, justice, teaching, collaborative work and learning.

Sybil S. Henderson is Assistant Dean and Lead Faculty of Leadership in the School of Business at North Carolina Central University, Durham, NC. Her research interests include authentic leadership, leadership assessment, and sustainability initiatives in colleges and universities. 


\section{REFERENCES}

Ajzen, I. (1988). Attitudes, personality, and behavior (U.S. ed.). Chicago, IL: Dorsey Press.

Baer, R. A., Smith, G. T., \& Allen, K. B. (2004). Assessment of mindfulness by self-report: The Kentucky inventory of mindfulness skills. Assessment, 11(3), 191-206.

Baglia, B.R. \& Hunt, J.G., (1988). An organizational life cycle approach to leadership. In Hunt, J.G., Baliga, B.R., Dachler, H.P. \& Schriesheim, C.A. (Eds.), Emerging Leadership Vistas. Lexington, MA: Lexington Books.

Baron, R. A. (2008). The role of affect in the entrepreneurial process. Academy of Management Review, 33(2), 328-340.

Bass, B. \& Riggio, R. (2006). Transformational leadership. Mahwah, NJ: Lawrence Erlbaum Associates.

Begley, T. M. \& Boyd, D. P. (1987). Psychological characteristics associated with performance in entrepreneurial firms and smaller businesses. Journal of Business Venturing, 2(1), 79-93.

Bird, B. (1992). The Roman God Mercury: An Entrepreneurial Archetype, Journal of Management Inquiry, 1, 205-213.

Bizzell, P. \& Herzberg, B. (2001). The Rhetorical Tradition, 2nd ed. Bedford/St Martin.

Boozer, R. (1998). Spirituality in management education. Journal of Workplace Learning, 10(6/7), 345-347.

Bryant, T. A. (2004). Entrepreneurship. In G. R. Goethals, G. J. Sorenson, and J.M. Burns (Eds.), Encyclopedia of Leadership (Vol. 1, pp. 442-448). Thousand Oaks, CA: Sage.

Burns, J.M., (1978). Leadership. New York: Harper and Row.

Cacioppe, R. (2000a). Creating spirit at work: Re-visioning organization development and leadership - Part I. Leadership and Organization Development Journal, 21(1), 48-54.

Cardon, M. S., Wincent, J., Singh, J., \& Drnovsek, M. (2009). The nature and experience of entrepreneurial passion. Academy of Management Review, 34(3), 511-532.

Cardon, M., Zeitsma, C., Saparito, P., Matherne, B., \& Davis, C. (2005). A tale of passion: New insights into entrepreneurship from a parenthood metaphor. Journal of Business Venturing, 20, 23-45.

Chanakya a.k.a. Kautilya (1992). The Arthashastra (original c. 350-283 BCE), L.N. Rangarajan, Ed., Penguin Classics, India.

Chandler, G. N. \& Hanks, S. H. (1994). Founder competence, the environment, and venture performance. Entrepreneurship Theory and Practice, 18, 77-89.

Chatterjee, Debasis (1998), Leading By Consciousness: A Pilgrimage Towards Self Mastery, New Delhi: Viva Books.

Chen, C-Y, Yang, C-Y \& Li, C-I. (2011). Spiritual Leadership, Follower Mediators, and Organizational Outcomes: Evidence from Three Industries across Two Major Chinese Societies, Journal of Applied Social Psychology, 42 (4), 890-938.

Chu, E. (2007). Spiritual Capitalism: The Achievement of Flow in Entrepreneurial Enterprises. Journal of Human Values, 13(1), 61-77.

Ciavarella, M.A., Buckholtz, A.K., Riordan, C.M., Gatewood, R.D. \& G.S. Stokes (2004). “The Big Five and venture survival: Is there a linkage? Journal of Business Venturing, 19, pp 465-483.

Cogliser, C. C. \& Brigham, K. H. (2004). The intersection of leadership and entrepreneurship: Mutual lessons to be learned. Leadership Quarterly, 15, 771-799.

Conger, J. A. (1989). Leadership: The art of empowering others. Academy of Management Executive, 3, 471482.

Darling, J., Keeffe, M. \& Ross, J. (2007). Entrepreneurial leadership strategies and values: Keys to operational excellence. Journal of Small Business and Entrepreneurship. 20 (1), 41-54.

Davidsson, P. \& Honig, B. (2003). The role of social and human capital among nascent entrepreneurs. Journal Business Venturing, 18, 301-31. 
Dellabarca, R. (2002), Understanding the Opportunity Recognition Process in Entrepreneurship, and Consideration of whether Serial Entrepreneurs Undertake Opportunity Recognition better than Novice Entrepreneurs, Dissertation, University of Cambridge, Judge Institute of Management.

Dent, E. B., Higgins, M. E., \& Wharff, D. M. (2005). Spirituality and leadership: An empirical review of definitions, distinctions, and embedded assumptions. Leadership Quarterly, 16, 625 - 653.

Diochon, M., Menzies, T. V. \& Gasse, Y. (2005). Exploring the relationship between start-up activities and new venture emergence: a longitudinal study of Canadian nascent entrepreneurs. International Journal of Management and Enterprise Development, 2(3), 408-426.

Duignan, P. \& Bhindi, N. (1997). Authenticity in leadership: An emerging perspective. Journal of Educational Administration, 35(3), 195-209.

Dyer, L. \& C. Ross. (2004). Learning from Experience in the Small Business: Potential Pitfalls in the Process. In T. Menzies (ed.), Proceedings of the Conference of the Administrative Sciences Association of Canada. Quebec, QC: ASAC, CD-ROM version.

Egan, K. (n.d.) Spirituality, Education and the Moral Life. http://www.sfu.ca/ egan/AERA-Spirituality.html [accessed Sep 7, 2012]

Ensley, M. D., Pearce, C. L. \& Hmieleski, K. M. (2006). The moderating effect of environmental dynamism on the relationship between entrepreneur leadership behavior and new venture performance. Journal of Business Venturing, 21(2), 243-263.

Feldbaumer, (1977), The Management of Growth: An entrepreneurial crisis, Doctoral Dissertation Abstract, American Journal of Small Business, 1(3), 38-39.

Fernando, M. (2008). Spiritual Leadership in Entrepreneurial Business: A Multifaith Study. Edward Elgar Publishing, Northhampton, USA.

Fiedler, F. E. (1967). A Theory of Effective Leadership. New York: McGraw-Hill.

Fishbein, M. \& Ajzen, I. (1975). Belief, Attitude, Intention and Behavior: An introduction to theory and research. Reading, MA: Addison-Wesley Pub.

Foo, M. D. (2011). Emotions and entrepreneurial opportunity evaluation. Entrepreneurship Theory and Practice, 35(2), 375-393.

Foo, M. D., Uy, M. A. \& Baron, R. A. (2009). How do feelings influence effort? An empirical study of entrepreneurs' affect and venture effort. Journal of Applied Psychology. 94(4), 1086-1094.

Ford, C.M. (1996). A Theory of Individual Creative Action in Multiple Social Domains, Academy of Management Review, 21, 1112-1142.

Fry, L. W. (2003). Toward a theory of spiritual leadership. Leadership Quarterly, 14(6), 693-728.

Gupta, V., MacMillan, I. C. \& Surie, G. (2004). Entrepreneurial leadership: Developing and measuring a crosscultural construct. Journal of Business Venturing, 19, 241-260.

Harvey, J. B. (2001). Reflections on books by authors who apparently are terrified about really exploring spirituality and leadership. The Leadership Quarterly, 12(3), 377-378.

Hersey, P. \& Blanchard, K. (1984). The Management of Organizational Behavior. Englewood Cliffs, NJ: Prentice Hall.

Hills, G.E. (1995). Opportunity recognition by successful entrepreneurs: A pilot study. Frontiers of Entrepreneurship Research, Babson College, Wellesley, MA, 103-121.

Howard, S. (2002). A spiritual perspective on learning in the workplace. Journal of Management Psychology, $17(3), 230-242$.

Howell, J. M. \& Hall-Merenda, K. E. (1999). The ties that bind: The impact of leader-member exchange, transformational and transactional leadership, and distance on predicting follower performance. Journal of Applied Psychology, 84(5), 680-694.

Jackson, J. \& Konz, G. 2006. Spirituality and entrepreneurship. Journal of Management, Spirituality \& Religion. 


\section{3(3), 242-257.}

Jensen, S. M. \& Luthans, F. (2006). The Relationship between Entrepreneurs' Psychological Capital and Authentic Leadership Dimensions. Journal of Managerial Issues, 18 (2), 254-273.

Karp, T. (2006). The inner entrepreneur: A constructivistic view of entrepreneurial reality construction. Journal of Change Management, 6(3), 291-304.

Kauanui, S. K, Thomas, K. D. \& Waters, G. R. (2005). Entrepreneurship and spirituality: integration of spirituality into the workplace. Journal of Management, Spirituality \& Religion, 2(2), 255-274.

Kauanui, S. K., Thomas, K. D., Sherman, C. L., Waters, G. R. \& Gilea, M. (2008). Exploring entrepreneurship through the lens of spirituality. Journal of Management, Spirituality \& Religion, 5(2), 160-189.

Khanna, H. \& Srinivas, E. (2000). Spirituality and leadership development. Presented to the roundtable conference on developing leaders, teams, and organizations: Meeting the challenges of global markets and technology, Management Development Institute, Guragon.

Konz G. \& Ryan, R. (1999). Maintaining an organizational spirituality: No easy task. Journal of Organizational Change, 12(3), 200-210.

Korac-Kakabadse, A. \& Korac-Kakabadse, N. (1997). Best practice in the Australian Public Service (APS): An examination of discretionary leadership. Journal of Managerial Psychology, 12(7), 187-193.

Korac-Kakabadse, N., Kouzmin, A. \& Kakabadse, A. (2002). Spirituality and leadership praxis. Journal of Managerial Psychology, 17(3), 165-182.

Kriger, M. \& Seng, Y. (2005), Leadership with inner meaning: A contingency theory of leadership based on the worldviews of five religions, Leadership Quarterly, 16, 771-806.

Krueger, N.F., Reilly, M.D. \& Carsrud, A.L. (2000). Competing Models of Entrepreneurial Intentions, Journal of Business Venturing, 15: 411-433.

LeBrasseur, R. \& J.T. Zinger (2005). Start-up Survival and Management Capability: A Longitudinal Study of Micro-enterprises, Journal of Small Business and Entrepreneurship, 18 (4), 409.

Levine, L. (1994). Listening with spirit and the art of team dialogue. Journal of Change Management, 7(1), 6173.

Luthans, F. \& B.J. Avolio. (2003). Authentic Leadership: A Positive Development Approach. In Positive Organizational Scholarship. Eds. K. S. Cameron, J. E.

Maharishi, Mahesh Yogi (1967). On the Bhagavad-Gita: A new translation and commentary, Chapters 1-6. Baltimore, Penguin Books.

Maharishi, Mahesh Yogi. (1994). Vedic knowledge for everyone. Vlodrop, Netherlands, Maharishi Vedic University Press.

Makhbul, Z. \& Hasun, F. (2011). Entrepreneurial Success: An Exploratory Study among Entrepreneurs. International Journal of Business and Management, 6(1), 116-125.

Mason, E. \& Welsh, A. (1994). Symbolism in managerial decision making. Journal of Managerial Psychology, 9(6), 27-35.

Mason, M. (2012). What Causes Small Businesses to Fail? http://www.moyak.com/papers/small-businessfailure.html.

McMahon, R. G. P., Holmes, S., Hutchinson, P. J. \& Forsaith, D. M. (1993). Small Enterprise Financial Management: Theory and Practice, Sydney: Harcourt Brace.

Mitchell, R, Busenitz, L., Bird, B., Gaglio, C.M., McMullen, J.S., Morse, E. \& Smith, B. (2007). Central Questions in Entrepreneurial Cognition Research. Entrepreneurship: Theory \& Practice, 31(1), 1-27.

Moberg, D. \& Calkins, M. (2001). Reflection in business ethics: Insights from St. Ignatius' spiritual exercises. Journal of Business Ethics, 33(3), 257-270.

Montoya, M. M., Omura, G. S. \& Calantone, R. (1993). Getting over the brick wall with the marketing manager. Research at the Marketing/Entrepreneurship Interface, 209-221. 
Morris, M., Schindehutte, M. \& LaForge, R. (2004). The emergence of entrepreneurial marketing: Nature and meaning. pp: 41-54 in H. Welsh (ed.), Entrepreneurship: The way ahead. New York: Routledge.

Moxley, R. S. (2000). Leadership and Spirit. San Francisco, CA: Jossey-Bass.

Norlyk, H.E., Schmidt, W.J. \& Heaton, D.P. (2009). Spiritual dimensions of entrepreneurship in Transcendental Meditation and TM-Sidhi program practitioners, Journal of Management, Spirituality and Religion, 6 (3): 195208.

Nothaft, H.R. \& Kline, D. (2011), Great Again: Revitalizing America's Entrepreneurial Leadership, BostonHarvard Business Review Press.

Oi, W. Y. (1983). Heterogeneous firms and the organization of production. Economic Inquiry, 21(2), 147-171.

Osho, (1980), The Orange Book: The Meditation Techniques of Bhagvan Shree Rajneesh, Ma Yoga Laxmi, Rajneesh Foundation, Bombay- Usha Offset Printers Pvt. Ltd.

Papalexandris, N. \& Galanaki, E. (2009). Leadership's impact on employee engagement: Differences among entrepreneurs and professional CEOs. Leadership and Organization Development Journal, 30(4), 365-385.

Peacock, R. (1985). Finding the Causes of Small Business Failure. Management Forum, 17, 77-89.

Prieto, L.C. (2010). Proactive Personality and Entrepreneurial Leadership: Exploring the Moderating Role of Organizational Identification and Political Skill, Academy of Entrepreneurship Journal, 16 (2), 107-121.

Sanders, J.E., Hopkins, W.E. \& Geroy, G.D. (2003). From transactional to transcendental: Toward an integrated theory of leadership. Journal of Leadership and Organizational Studies, 9(4), 21-31.

Sashkin, M. (1988). The Visionary Leader. In J. A. Conger and R. N. Kanungo (Eds.), Charismatic Leadership: The elusive factor in organizational effectiveness (pp. 122-160). San Francisco: Jossey-Bass.

Shane, S. (2008). The Illusions of Entrepreneurship. New Haven, CT: Yale University Press.

Smith, K.G. \& Gannon, M.J. (1987). Organizational Effectiveness in Entrepreneurial and ProfessionallyManaged Organizations, Journal of Small Business Management, 25 (3), 14-21.

Song, M., Podoynitsyna, K., Van Der Bij, H. \& Halman, J. I. M. (2008). Success Factors in New Ventures: A Metaanalysis. Journal of Product Innovation Management, 25: 7-27.

Sosik, J.J., Kahai, S.S. \& Avolio, B.J. (1998). Transformational Leadership and Dimensions of Creativity: Motivating Idea Generation in Computer-Mediated Groups. Creativity Research Journal, 11, 111-21.

Stewart, G. \& Manz, C. (1995). Leadership for self-managing work teams: A typology and integrative model. Human Relations, 48(7), 747-770.

Strubler, D. \& Redekop, B. (2010). Entrepreneurial Human Resource Leadership: A Conversation with Dwight Carlson. Human Resource Management, 49 (4), 793-804.

Stuart, T. E. \& Sorenson, O. (2007), Strategic networks and entrepreneurial ventures. Strategic Entrepreneurship Journal, 1 , 211-227.

Thornhill, S. \& Amit, R (2003), Learning from Failure: Bankruptcy, Firm Age and the Resource-based View, Organization Science, 14 (5), 497-509.

Tosey, P. \& Robinson, G. (2002). When change is no longer enough: What do we mean by transformation in organizational change work? The TQM Magazine, 14(2), 100-109.

Travis, F. \& Arenander, A. (2006). Cross-sectional and longitudinal study of effects of Transcendental Meditation practice on inter-hemispheric frontal asymmetry and frontal coherence. International Journal of Neuroscience, 116(12): 1519-1538.

Venkataraman, S. \& Van de Ven, A.H., (1998). Hostile environmental jolts, transaction sets and new business development. Journal of Business Venturing, 13(3), 231-255.

Villette, M. \& Vuillermot, C. (2009). From Predators to Icons: Exposing the myth of the business hero. Ithaca, NY: Cornell University Press.

Wallace, R.K. (1993). The Physiology of Consciousness. Fairfield, IA. Maharishi University of Management Press. 
Westhead, P. \& Birley, S. (1995). Employment growth in new independent owner-managed firms in Great Britain. International Small Business Journal, 13(3), 11-34.

Yildrim, H. \& Saygin, S. (2011). Effects of Owners' Leadership Style on Manufacturing Family Firms' Entrepreneurial Orientation in the Emerging Economies: An Empirical Investigation in Turkey, European Journal of Economics, Finance and Administrative Sciences, 32, 26-32.

Zaccaro, S. \& Banks, D. (2001). Leadership, vision, and organizational effectiveness. In S. J. Zaccaro and R. J. Klimoski (Eds.), The Nature of Organizational Leadership: Understanding the performance imperatives confronting today's leaders. San Francisco: Jossey-Bass.

Zaccaro, S., Rittman, A. \& Marks, M. (2001). Team leadership. Leadership Quarterly, 12(4), 451-483.

Zimmerer, T.W. \& N.M. Scarborough. (2002). Essentials of Entrepreneurship and Small Business Management. Upper Saddle River, NJ: Prentice Hall. 